\title{
Patterns of Ant (Hymenoptera: Formicidae) Richness and Relative Abundance along an Aridity Gradient in Western Venezuela
}

\author{
AJ Pérez-Sánchez ${ }^{1,3}$, Je LatTKe ${ }^{2}$, Al Viloria ${ }^{1}$ \\ 'Lab de Biología de Organismos, Centro de Ecología, Instituto Venezolano de Investigaciones Científicas (IVIC), Caracas, Venezuela \\ ${ }^{2}$ Museo del Instituto de Zoología Agrícola, Univ Central de Venezuela, Maracay, Venezuela \\ ${ }^{3}$ Lab de Ecología Sensorial, Centro Multidisciplinario de Ciencias, Instituto Venezolano de Investigaciones Científicas \\ (IVIC-Mérida), Merida, Venezuela
}

\section{Keywords}

Ant diversity, Araya Peninsula, Mantel correlograms, neotropics, semi-arid environments

\section{Correspondence}

AJ Pérez-Sánchez, Lab de Ecología Sensorial, Centro Multidisciplinario de Ciencias, Instituto Venezolano de Investigaciones Científicas

(IVIC-Mérida), Apartado 20632, Caracas 1020-A, Venezuela; ajperez@ivic.gob.ve

Edited by Kleber del Claro - UFU

Received 10 August 2012 and accepted 6 November 2012

Published online 21 December 2012

(C) The Author(s) 2012. This article is published with open access at Springerlink.com

\begin{abstract}
In xeric ecosystems, ant diversity response to aridity varies with rainfall magnitude and gradient extension. At a local scale and with low precipitation regimes, increased aridity leads to a reduction of species richness and an increased relative abundance for some ant species. In order to test this pattern in tropical environments, ant richness and relative abundance variation were evaluated along $35 \mathrm{~km}$ of an aridity gradient in the Araya Peninsula, state of Sucre, Venezuela. Three sampling stations comprising five transects each were set up. Pitfall traps and direct collecting from vegetation were assessed per transect. Overall, 52 species, 23 genera, and 7 subfamilies of ants were recorded in the peninsula. The total number of species and genera recorded by both sampling stations and transects decreased linearly with increasing aridity. Total relative abundance was highest in the most arid portion of the peninsula, with Crematogaster rochai (Forel) and Camponotus conspicuus zonatus (Emery) (Hymenoptera: Formicidae) being the numerically dominant species. Spatial and multivariate analyses revealed significant changes in ant composition every $11 \mathrm{~km}$ of distance, and showed a decrease of ant diversity with the increase of harsh conditions in the gradient. Here, we discuss how local geographic and topographic features of Araya originate the aridity gradient and so affect the microhabitat conditions for the ant fauna.
\end{abstract}

\section{Introduction}

Changes in ant diversity along broad-scale transitions, ecotones, and gradients have been an important objective of myrmecological studies in arid environments during the last decades (Andersen 1997, Pfeiffer et al 2003, Reznikova 2003, Dunn et al 2009). Ant variation along aridity gradients have been assessed through several approaches, ranging from natural transition evaluations to habitat disturbance studies, including altitudinal and precipitation gradient surveys (Andersen 1997, Kaspari et al 2000, Bestelmeyer \& Wiens 2001, Araújo \& Fernandes 2003, Pfeiffer et al 2003, Sanders et al 2003, Gunawardene \& Majer 2004, Delsinne et al 2010). In general, aridity gradients are correlated with significant changes in vegetative component and coverage as a consequence of the precipitation and temperature variation effect on net primary productivity (Schulze et al 1996, Scholes et al 2002, Tieleman et al 2003, Petrů et al 2006). Although animal richness tends to increase along with such variables within aridity gradients (Mittelbach et al 2001), the response of ant assemblages to aridity variations depend upon rainfall intensity and scale of the study (Davidson 1977, Morton \& Davidson 1988, Medel 1995, Kaspari et al 2000, Delsinne et al 2010). However, several studies have revealed that rising aridity leads to a reduction in ant richness, as well as an increase in the abundance of some species within ant assemblages (Whitford 1978, Marsh 1986, Sanders et al 2003, Gunawardene \& Majer 2004).

The Araya Peninsula is one of the driest localities in Venezuela, with some years of no precipitation at all 
(Cumana 1999, Thielen 2003). Although there are no accurate rainfall records along the peninsula's extension, several authors recognize an aridity gradient from east to west based on the erratic behavior of precipitation, temperature variation, and significant changes in the vegetation (Guevara et al 1992, Cumana 1999, González et al 2004). According to climatic estimations by Thielen (2003), this decrease in rainfall starts from near of the peninsula base (Caimancito town) towards the western tip of the region (Fig 1). In the last 20 years, there have been several publications of faunistic and floristic information for this region, mainly the eastern side (Guevara et al 1992, Lentino \& Bruni 1994, Cumana 1999, Cumana et al 2000, Cornejo \& Prieto 2001, Cumana \& Cabeza 2003, Leopardi et al 2009). However, information about biotic turnover along the peninsula is limited to lizard fauna (González et al 2004), while functionally important groups, such as ants, are completely unknown. Therefore, the aim of this work was to evaluate ant richness and relative abundance changes along the aridity gradient of the Araya Peninsula, State of Sucre, Venezuela. Considering the premise that aridity limits ant diversity in terms of resource availability, physiological stress, and increased competition (Andersen 1997, Bestelmeyer 2000, Pfeiffer et al 2003, Reznikova 2003, Sanders et al 2003), we expect a decrease of ant richness and a higher presence of numerically dominant species (sensu Davidson 1998) in proportion to the increasing aridity gradient from east to west. To test this hypothesis, we evaluated changes in these parameters with a taxonomic (species and genera) and spatial (sampling stations and transects) approach along $35 \mathrm{~km}$ of gradient (Fig 1).

\section{Material and Methods}

The Araya Peninsula is located in State of Sucre, eastern Venezuela (Fig 1). It occupies $652 \mathrm{~km}^{2}$ with a length of $60 \mathrm{~km}$ and a width between 4 and $24 \mathrm{~km}$ (Cumana 1999, González et al 2004). There are a series of low and narrow central hills that increase in altitude from west $(<100 \mathrm{~m})$ to east, reaching their highest point $(600 \mathrm{~m})$ in the southeastern peninsula (Ewel \& Madriz 1976, Cumana 1999, González et al 2004). The climate is arid at the western edge and semi-arid toward the east due to the combined effect of maritime-continental winds and topography (Ewel \& Madriz 1976, Cumana 1999, González et al 2004). Given the absence of meteorological stations in the peninsula, the annual mean precipitation is either frequently cited, calculated, or extrapolated from the 1984-1990 records of

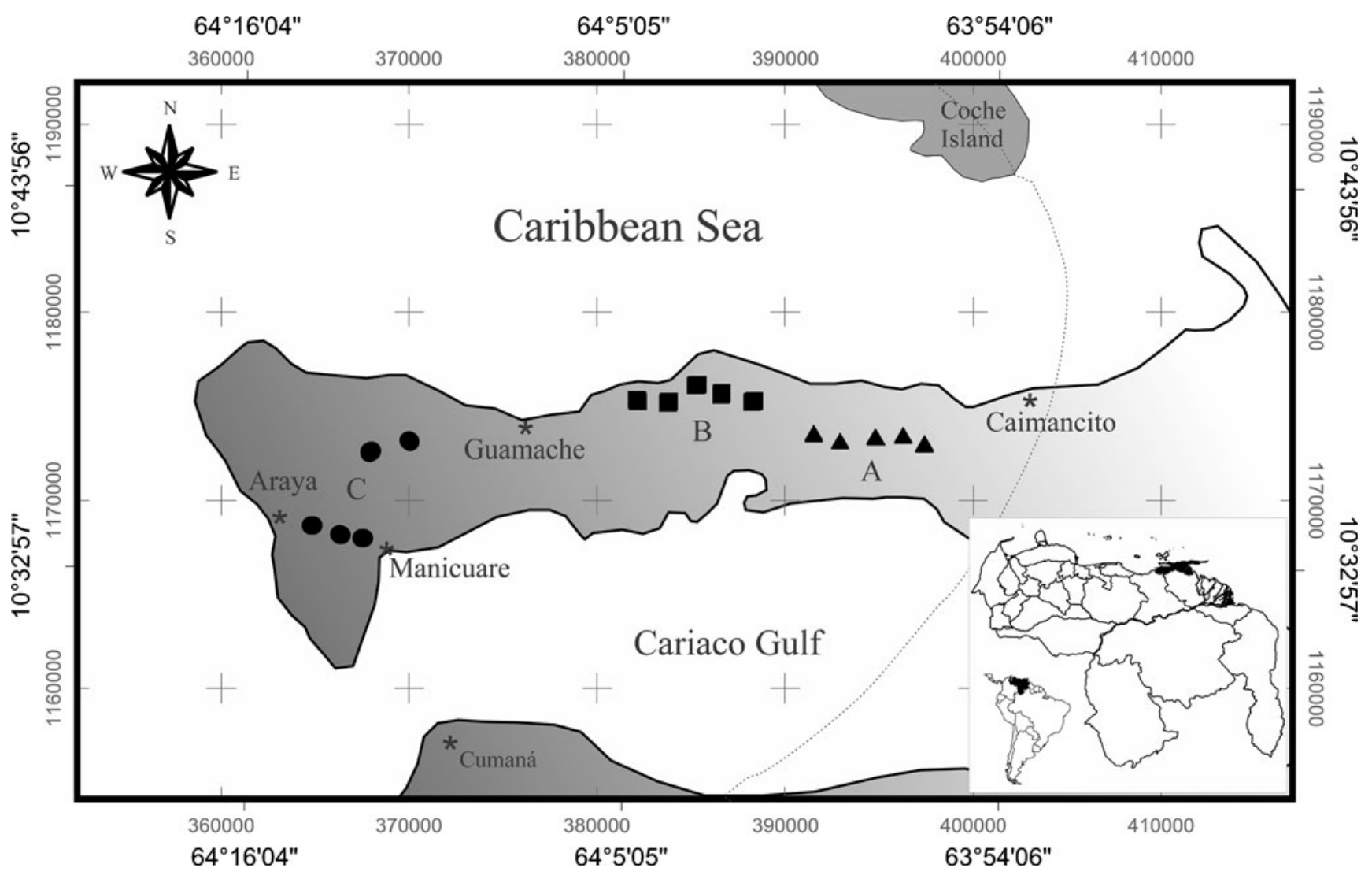

Fig 1 Geographic location of the Araya Peninsula, State of Sucre, Venezuela. The map shows the location of sampling stations $(A, B$, and $C)$ and transects (geometric symbols) within the aridity gradient (gray area). The dotted line indicates the precipitation change suggested by Thielen (2003). The gray values are UTM geographic coordinates (zone 20). 
the Guayacán, Cumaná, Cariaco, and San Pedro de Coche weather stations (Guevara et al 1992, Leopardi et al 2009). The annual mean precipitation varies between 500 and $800 \mathrm{~mm}$ at the peninsula base, and decreases to $243.8 \mathrm{~mm}$ towards the western tip (Guevara et al 1992, Thielen 2003, Leopardi et al 2009). There are eight dry months during August-November and February-May, and two periods of precipitation during December-January and June-July (Guevara et al 1992). The annual mean temperature is $27.3^{\circ} \mathrm{C}$ and soil textures vary from loamy clays to loamy silt (Matteucci 1986, Leopardi et al 2009).

The vegetation is represented by 221 recorded angiosperm species that form four general landscape types: coastal herb plains, mangroves, savanna, and xerophilous shrublands (Cumana 1999, González et al 2004). Coastal herb plains have halophytic and psammophylic species which represent the lower strata along the northern coast (Cumana 1999). Mangroves correspond to woody formations located in wet and salty soils, which form small, isolated, and dispersed groups of Rhizophora mangle (Rhizophoraceae), Avicennia germinans (Acanthaceae), Conocarpus erectus, and Laguncularia racemosa (Combretaceae) (Cumana 1999). The Savanna is located in the central region of the peninsula and is dominated by the grasses Aristida, Bouteloua, Digitaria, Eragrostis, Paspalum, and Trachypogon (Cumana 1999). This vegetative formation exhibits a poor but well-defined arboreal stratum: Byrsonima crassifolia (Malpighiaceae), Mabea occidentalis (Euphorbiaceae), and Roupala montana (Proteaceae).

The xerophilous shrubland is the dominant formation and is mostly woody plants, trees, shrubs, vines, and epiphytic-hemiparasitic species, with a clear predominance of cacti and deciduous armed legumes in the canopy (Cumana 1999). Height and abundance of woody species allow recognizing two physiognomies, cactus scrubs and thorny shrublands (González et al 2004). The former is located from the western tip to Chacopata hill, and is characterized by legume species with heights below $5 \mathrm{~m}$ and columnar cacti that barely reach $3 \mathrm{~m}$ (González et al 2004). The thorny shrubland distributed from the central region to the eastern side of the peninsula, and has a greater proportion of woody and succulent cacti that surpass $8 \mathrm{~m}$ in height (González et al 2004). Both vegetation types have abundant Prosopis juliflora (Mimosaceae) and Caesalpinia granadillo (Caesalpinaceae), as well as Stenocereus griseus, Cereus repandus, and Pereskia guamacho (Cactaceae). Other common species belong to the following genera: $\mathrm{Eu}$ phorbia, Croton, Panicum, Paspalum, Digitaria, and Opuntia (Cumana 1999, González et al 2004).

\section{Ant sampling}

Three sampling stations below $100 \mathrm{~m}$ of altitude were chosen in the westernmost $35 \mathrm{~km}$ of the peninsula, from
Caimancito to Araya town (A, B, C; Fig 1). Each station corresponds to a 6-km lineal plot with five parallel transects of 130-m length, 10- $\mathrm{m}$ width, and $1.5-\mathrm{km}$ separation between each other. All transects were located randomly in savannas or xerophilous shrublands in order to avoid flooded and unsuitable conditions for ground-dwelling ants (e.g., coastal plains and mangroves). Ants were sampled using ten pitfall traps along each transect with $13 \mathrm{~m}$ of spacing between each other. All traps were simultaneously active during $c a .72 \mathrm{~h}$ in June 2009. Traps were plastic containers with $90-\mathrm{cm}$ diameter and $120 \mathrm{ml}$ of capacity, filled with $70 \mathrm{ml}$ of $70 \%$ ethanol, $11 \%$ monoethylene glycol and few drops of liquid soap. Therefore, the total sampling effort was 50 traps per sampling station, with 150 traps for the whole peninsula (ten traps $\times$ five transects $x$ three sampling stations). Additionally, direct sampling was carried out on woody dominant vegetation (tree or shrub species) during trap installation (1000-1600 hours). At each transect ten individual plants with heights between 1.5 and $2.5 \mathrm{~m}$ were randomly selected and searched during $5 \mathrm{~min}$. A total effort of 250 and 750 min of direct sampling was accomplished for each sampling station and the peninsula, respectively $(5 \min \times 10$ plants $\times 5$ transects $\times 3$ sampling stations). Ants were sorted and identified to species or morpho-species level using taxonomic keys for the Neotropical region (Palacio \& Fernández 2003) and comparing them with museum specimens from the Museo del Instituto de Zoología Agrícola (MIZA), Universidad Central de Venezuela (UCV), Maracay-Venezuela. Voucher specimens were deposited in the MIZA.

\section{Richness estimation and data transformation}

The EstimateS 8.2 (Colwell 2009) application was used to calculate second-order Chao (Chao2) and first-order Jackknife (JK1) estimators for each sampling station and the peninsula as a whole. These estimators take into account both, species with high frequency of capture and species with low frequency of occurrence considered as unique in incidence data terms (Colwell et al 2004, Colwell 2009). All estimations used incidence data with 100 randomizations of sample order.

Relative abundance in traps was standardized to reduce the marked variations among species records. First, adjusted abundance (AA) was calculated to evaluate ant abundance at sampling station level using the following formula: $\mathrm{AA}=(\mathrm{A}) \times(\mathrm{O} / 100)$, being $A$ the total number of individuals of each species, and $O$ the occurrence or percentage of traps in which each species is present (Lindsey \& Skinner 2001). This method combines abundance with percentage of occurrence in a value and reduces the effect of traps being near nests or trunk trails (Lindsey \& Skinner 2001, Pérez-Sánchez 2007, Pérez-Sánchez et al 2012). Second, we generated a data matrix calculating the natural logarithm 
of the abundance of species plus $1[\operatorname{Ln}(A+1)]$ per trap in order to explore ant abundance variation along the aridity gradient, and perform further multivariate analysis.

\section{Gradient analysis}

Since the aridity gradient in Araya parallels longitudinal change throughout the study area, we considered the east to west transition as a proxy of the gradient. Therefore, the geographic coordinates in meters of each trap and transect were used as spatial location data according to the Universal Transverse Mercator system (UTM, zone 20) (Fig 1). Linear and polynomial regression analyses were performed between the spatial location of each transect (independent variable) and ant diversity parameters (dependent variables) in order to establish the pattern of variation in the ant assemblage along the gradient. Ant richness was considered as the sum of species or genera records obtained by both sampling methods per transect, while relative abundance was data exclusively taken from traps considering the collecting methods as complementary rather than additive for abundance estimation (Bestelmeyer et al 2000).

Mantel correlograms were constructed for establishing the variation in species composition ( $\beta$ diversity) per spatial location of each trap. Dividing Mantel correlations into classes of discrete geographical distances, this analysis makes it possible to establish if geographically closest samples show higher similarity in their composition (Oden \& Sokal 1986, Legendre \& Legendre 1998). In our case, the main advantage of this analysis is to determine the geographic distance at which species composition (measured as dissimilarity) changes within ant assemblages. Bray-Curtis dissimilarity values for ant species were used as biotic matrix (dependent variable) and location data $(x, y)$ as geographical matrix (independent variable). Spearman coefficient and Mantel statistic with permutation tests were used due to the nonparametric behavior of the data. Dissimilarity calculations, Mantel correlograms, and permutations tests were performed using vegdist and mantel.correlog commands included in the Vegan package of the R 2.13.2 statistical program (R Development Core Team 2011, Oksanen et al 2011).

Additionally, a two-indicator species analysis (TWINSPAN) was performed using an abundance matrix of species per traps. This method is a divisive and hierarchical classification that produces successive dichotomies in the formed groups from the weighted averages of species and samples (Legendre \& Legendre 1998, McCune \& Mefford 1999). This feature allows us to sort simultaneously both, species and groups of traps (sample units, SU) along the studied gradient. We conducted this analysis using the PC-ORD 4.0 statistical package (McCune \& Mefford 1999).

\section{Results}

We recorded about 40,000 ant specimens from 52 species, 23 genera, and 7 subfamilies ["Electronic supplementary material" (ESM) 1]. Overall, 49 species and 23 genera were recorded using pitfall traps, while 20 species and 11 genera were detected through direct sampling (Table 1, ESM 1). Only three species were recorded exclusively by manual technique (ESM 1). The total number of species recorded for the peninsula was close to the values predicted by both estimators (Table 1), indicating that about $95 \%$ of terrestrial ants and more than $77 \%$ of arboreal and diurnal species were collected in the peninsula. Ant genera and species richness decreased from sampling stations $A$ to $C$, with the highest terrestrial and arboreal ant richness in the eastern peninsula (station A; Table 1). Although observed richness values are close to those predicted by the estimators of both sampling techniques, Chaor estimation and confidence boundaries differ from JK1 predicted values, suggesting that at least ten species of arboreal ants eluded capture in station A (Table 1). Such differences between estimators are due to the high number unique and the absence of duplicates, which increase Chao2 in relation to JK1 (Colwell 2009). Additionally,
Table 1 Richness of ant species and genera along the aridity gradient.

Number of species and genera observed are estimated $( \pm \mathrm{SD})$ at the peninsula and sampling station level.

Chao2 Chao second order results, JK1 Jackknife first order results.

\begin{tabular}{|c|c|c|c|c|c|c|c|c|}
\hline \multirow[t]{2}{*}{ Richness } & \multicolumn{2}{|c|}{ Peninsula } & \multicolumn{2}{|c|}{ Station A } & \multicolumn{2}{|c|}{ Station B } & \multicolumn{2}{|c|}{ Station C } \\
\hline & Species & Genera & Species & Genera & Species & Genera & Species & Genera \\
\hline \multicolumn{9}{|c|}{ Traps collect } \\
\hline Observed & 49 & 23 & 42 & 22 & 30 & 15 & 21 & 12 \\
\hline Chao2 & $52 \pm 3$ & $24 \pm 2$ & $45 \pm 3$ & $23 \pm 1$ & $33 \pm 3$ & $15 \pm 1$ & $26 \pm 6$ & 12 \\
\hline JK1 & $56 \pm 3$ & $26 \pm 2$ & $49 \pm 4$ & $25 \pm 2$ & $35 \pm 2$ & $17 \pm 1$ & $26 \pm 2$ & $13 \pm 1$ \\
\hline \multicolumn{9}{|c|}{ Direct sampling } \\
\hline Observed & 20 & 11 & 20 & 11 & 11 & 9 & 6 & 6 \\
\hline Chao2 & $26 \pm 6$ & 11 & $32 \pm 10$ & $13 \pm 3$ & $13 \pm 4$ & 9 & $7 \pm 2$ & 5 \\
\hline JK1 & $26 \pm 3$ & 11 & $30 \pm 4$ & $14 \pm 2$ & $13 \pm 1$ & $10 \pm 1$ & $8 \pm 1$ & $6 \pm 1$ \\
\hline Total & 52 & 23 & 46 & 23 & 31 & 16 & 22 & 12 \\
\hline
\end{tabular}


genera richness showed a strong decrease from east to west in a similar way that species richness values (Table 1).

Species and genera richness for each transect showed a significant linear decrease from east to west $(P<0.005$; Fig 2), with specific richness, the parameter that best fits the linear model $(F=26.65, d f=15, P=0.0002$; Fig 2a). Although genera richness showed significant correlations with trap spatial arrangement, the association between both variables barely exceeds $55 \%$ ( $P<0.005$; Fig $2 b$ ). In terms of abundance, the AA values of species described a significant non-linear (quadratic polynomial) increase along the spatial transition of the gradient $(P=0.004)$; however, the association between ant abundance and gradient was not high (59\%) (Fig 3). Note that species richness and relative abundance of the second transect in sampling station $\mathrm{C}\left(\mathrm{C}_{2}\right)$ differs from those recorded at the same site
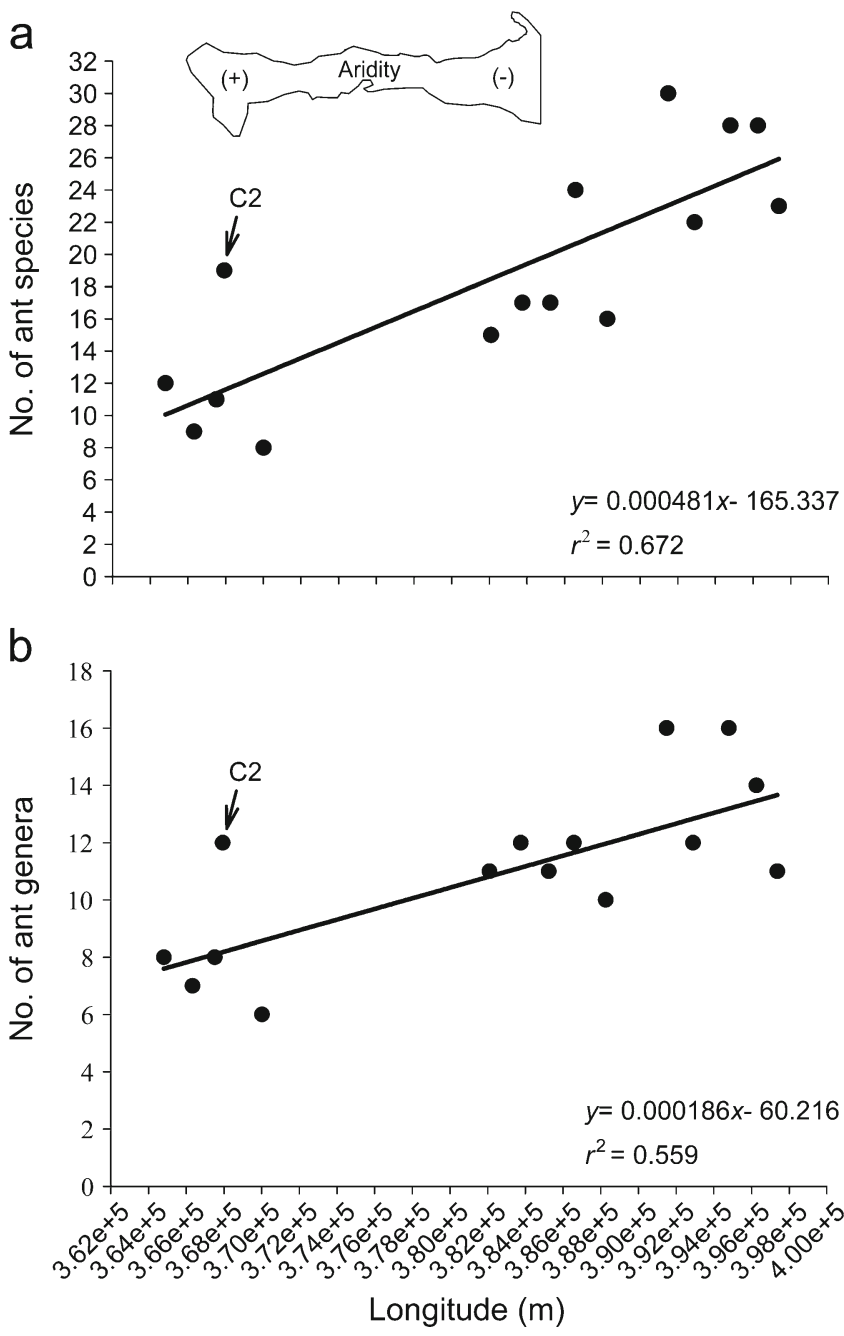

Fig 2 Relationship between ant species richness and longitudinal variation (aridity gradient) in Araya Peninsula, State of Sucre, Venezuela. Each point represents the total richness values of ant species (a) and genera (b). The line is a best fit regression model. The acronyms $C 2$ indicates the values recorded in the second transect of sampling station $\mathrm{C}$.

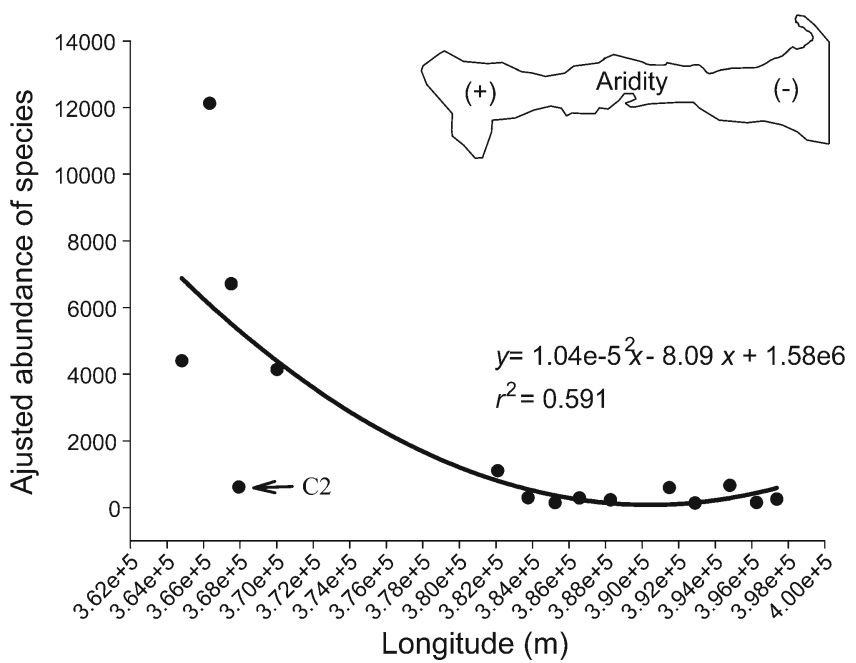

Fig 3 Relationship between the species adjusted abundance and longitudinal variation (aridity gradient) in Araya Peninsula, State of Sucre, Venezuela. Each point represents the adjusted abundance values of species in traps. The line corresponds to the regression model that best fit the data (quadratic polynomial regression). The acronym $C 2$ indicates the $A A$ values recorded in the second transect of sampling station $\mathrm{C}$.

(Figs 2 and 3). Since these results probably increase data variation and skewed the studied pattern, we reassessed the regression analyses excluding $\mathrm{C}_{2}$ data. The results showed a similar but more robust trend, where ant richness decreases linearly along with increasing aridity $\left(r^{2}=\right.$ 0.77 for species, $r^{2}=0.63$ for genera, $\left.P<0.05\right)$, while relative abundance maintains a non-linear (quadratic polynomial) increase from east to west $\left(r^{2}=0.75, P=0.004\right)$.

Significant spatial correlation values between $\beta$ diversity and trap locations at five classes of discrete geographical distances were observed $(P<0.005)$, the association between both variables decreasing with increasing separation between samples (Fig 4). Mantel (Spearman) statistics were low (10-20\%), but their significance and positive value indicated the mean similarity in the first classes of distance was greater than the mean similarity between the other classes of distance (Fig 4). Therefore, similarity in ant composition between traps was higher in those samples separated less than $11 \mathrm{~km}$ than for traps with wider separation (Fig 4).

TWINSPAN classification analysis generated three divisions, six groups of $\mathrm{SU}$, and nine indicator species from the 49 species and 150 samples analyzed (pitfall traps) (Fig 5). In the first division, 29 samples were separated in the positive $\mathrm{SU}$, mostly composed by samples from transects A1-2 and A3-4 (Fig 5a). Indicator species for this set were Pheidole sp. R1, Ectatomma ruidum (Roger), and Solenopsis sp. 1; while Dorymyrmex brunneus (Forel) and Camponotus conspicuus zonatus (Emery) characterized the 121 samples of the negative group. The second division occurred in the SU mentioned before (121 samples), where the positive branch 


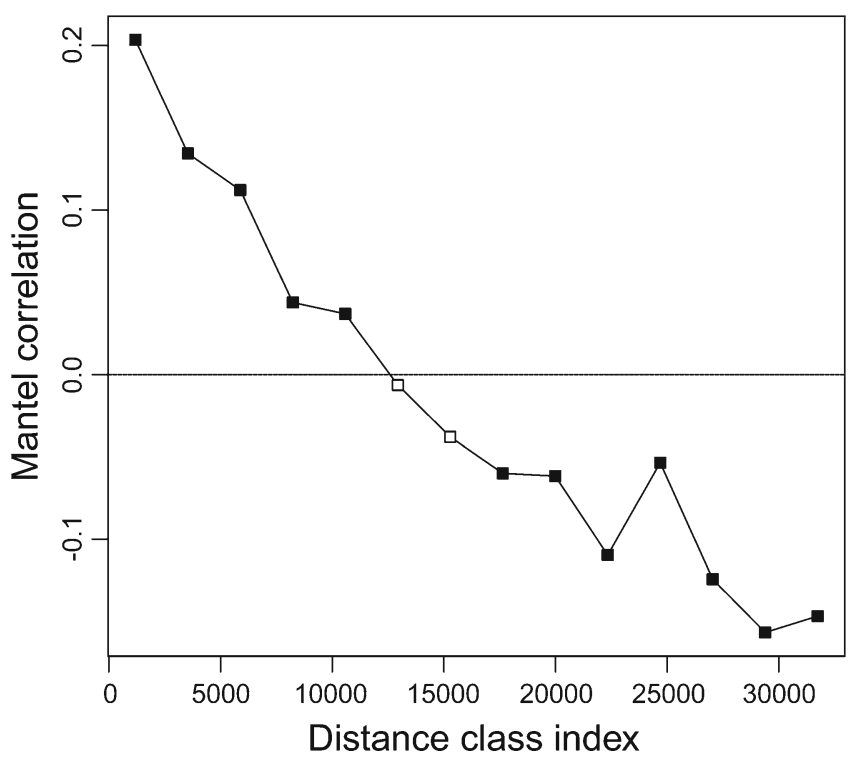

Fig 4 Mantel correlograms for the ant assemblages and longitudinal variation (aridity gradient) in Araya Peninsula, State of Sucre, Venezuela. Correlograms represent the spatial association pattern between ant composition and the geographical location of pitfall traps. The filled boxes represent the Mantel coefficient values that differ from the expected by chance $(p<0.05)$, the empty boxes represent the not significant Mantel statistic values $(p>0.05)$.

showed 78 samples and the negative had 43 samples (Fig $5 a$ ). The indicators species for this dichotomy were Solenopsis globularia (Smith), Acromyrmex rugosus (Smith), and Crematogaster obscurata (Emery) for positive SU; whereas Crematogaster rochai (Forel) and C. conspicuus zonatus were indicators for the negative branch. No division was performed in the last negative group, mainly composed by traps from sampling station C (Fig 5a). The third split was performed in the last positive group (78 SU), resulting in two final groups of $38 \mathrm{SU}$ (negative branch), and $40 \mathrm{SU}$ (positive branch). In the negative branch, about $89 \%$ of the samples corresponded to data from transects $\mathrm{B} 1-2, \mathrm{~A} 3-5$, and $\mathrm{C} 2$; with Camponotus lindigi (Mayr) and C. obscurata as indicator species (Fig 5a). In the positive group, the main contribution was from B4-5, B1-2-5, and A4-5 transects with Kalathomyrmex emeryi (Forel) and D. brunneus as indicator species (Fig 5a). The spatial distribution of the SU generated by TWINSPAN complements the Mantel correlogram results and showed changes in the composition and abundance of ants along the gradient (Fig $5 \mathrm{~b}$ ). Note that as in the regression analyses, data from $\mathrm{C}_{2}$ differ in respect to the other transects within the sampling station C (Fig 5b).

\section{Discussion}

This work represents the first systematic survey of ants in the Araya Peninsula, and shows similar patterns to that observed in vegetation and herpetofauna richness in the region (Cumana 1999, González et al 2004). The variation in ant richness and relative abundance along the peninsula suggests the existence of an aridity gradient, at least in the westernmost $35 \mathrm{~km}$. Considering the decrease in precipitation and net primary productivity as indicators of aridity, our results seem to match those reported for ant assemblages in arid locations of Africa and EEUU (Davidson 1977, Marsh 1986, Andersen 1997, Kaspari et al 2000, Sanders et al 2003), but contrast with those found in deserts and semi-deserts of Australia, Asia, and South America (Morton \& Davidson 1988, Medel 1995, Pfeiffer et al 2003, Delsinne et al 2010). This ambiguity may be explained by Delsinne et al (2010) considerations on ant diversity and rainfall occurrence relationship in arid environments. These authors argue that the decrease of rainfall in arid environments does not exert negative effects on alpha diversity at regional and intercontinental scales (variations over of $400 \mathrm{~km}$ ), while local studies in environments with low rainfall $(>300 \mathrm{~mm})$ show ant diversity decreases with increasing aridity (Davidson 1977, Marsh 1986, Sanders et al 2003). Therefore, our results agree with Delsinne et al (2010) due to local extension of the gradient $(<100 \mathrm{~km})$ and the erratic precipitation regime $(>500 \mathrm{~mm})$ in the Araya Peninsula.

Although rainfall variation is a common denominator in gradients of aridity, the gradient in Araya responds to a combination of atmospheric and topographic factors, rather than decline in rainfall per se (Ewel \& Madriz 1976, Cumana 1999). In contrast to surrounding mesic locations (e.g., Paria Peninsula), the low relief of Araya offers less resistance to passing air masses (trade, sea, and land winds) which move and intensify along the same longitudinal direction of the peninsula (Ewel \& Madriz 1976, Cumana 1999). These air masses absorb and transport humidity from lowlands at the northern border of the peninsula to the western tip and central-eastern elevations, contributing with the decrease in relative humidity and erratic behavior of rainfall (Ewel \& Madriz 1976, Cumana 1999). Consequently, besides a longitudinal gradient of aridity, there is also a decrease of xeric conditions with increased elevations due to a rainfall shadow effect (Ewel \& Madriz 1976, Cumana 1999). In this case, we would expect an increase in ant diversity along with elevation, where lower temperatures and higher precipitations may support higher levels of primary production and favorable habitat conditions for ants (Araújo \& Fernandes 2003, Sanders et al 2003, Pérez et al unpublished data). Therefore, the complexity of vegetation and animal assemblages is expected to decrease proportionally with altitudinal and longitudinal aridity changes in Araya. Although elevation may be favorably conditioning habitat for ants, our survey did not contemplate altitudinal variation and all sampling 


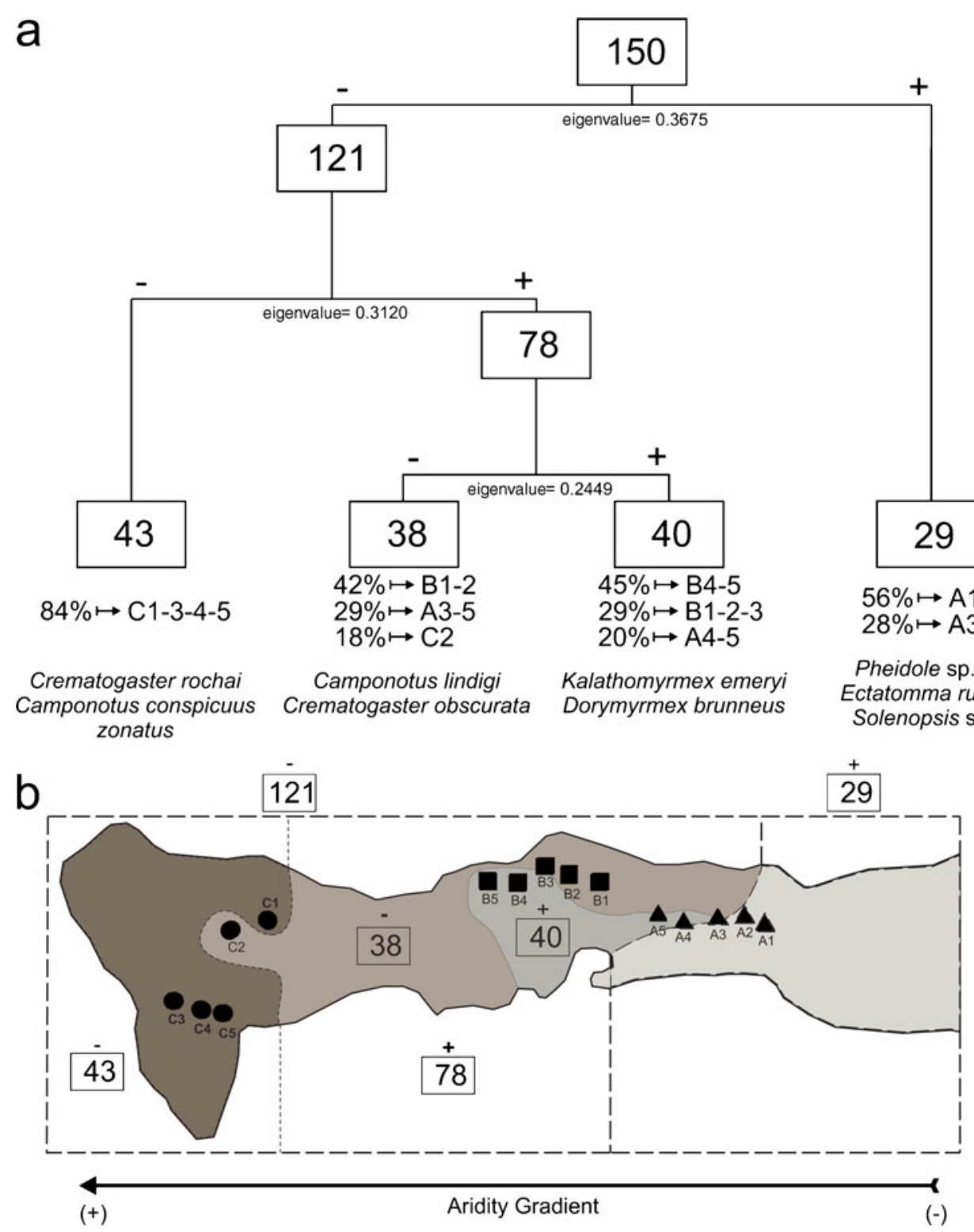

Fig 5 TWINSPAN classification analysis for the ant assemblage in Araya Peninsula, State of Sucre, Venezuela. a Classification of 49 species and 150 samples (pitfall traps), the values in boxes indicate the number of sample units (SU) per division, percentages indicate the contribution of samples from each transect, and the names in italics are the indicator species for each final SU, b Geographical representation of the TWINSPAN results within the peninsula, dotted black lines represent the division dichotomies and the shades of grays indicate the SU variation along the gradient. stations were located below $150 \mathrm{~m}$ of altitude. Therefore, further studies would be needed to explore such altitudinal relationship.

All sampling levels (station, transect, trap, and vegetation) showed a decrease in ant richness along the aridity gradient for both, species and genera. Species richness was the best gradient descriptor as it decreased linearly with the gradient, indicating higher resource availability and favorable microhabitat conditions in the base than the western region of the peninsula. Spatial analyses indicate species turnover may be explained by spatial location (indirect measure of the aridity gradient) in the first classes of distances, which means that changes in ant composition can be detected every $11 \mathrm{~km}$ of distance. This is also supported by the turnover of indicator species and the overlap between the multivariate classification and spatial gradient. For example, Pheidole sp. R1 and Solenopsis sp. 1 are found in less arid habitats of eastern Araya and were absent in the rest of the region, while $A$. rugosus was representative of the middle gradient due to their high frequency in traps from intermediate sites, confirming its affinity to xeric regions with intermediate or disturbed vegetation (Pérez-Sánchez 2007). Finally, D. brunneus, C. conspicuus zonatus, and $C$. rochai were indicator species for the rest of the region due to their ubiquity throughout the peninsula.

Our results indicate an increased numerical dominance of $C$. rochai and $C$. conspicuus zonatus paralleling the longitudinal gradient. This high incidence and relative abundance in the most arid part of Araya can be based 
on their natural history and the absence of behavioral dominant ants such as Solenopsis geminata or Pheidole fallax in the west side of the peninsula (Andersen 1995, 1997, Reznikova 2003, Pérez-Sánchez 2007, Pérez-Sánchez et al 2012). Crematogaster rochai has polydomic nests, diurnal foraging activity, and moderately aggressive massive recruitment (Longino 2003), which may favor greater accessibility to resources as well as habitat colonization by expansion (clonal expansion sensu Stanton et al 2002). Therefore, we expect $C$. rochai to be a successful forager and colonizer in sites with reduced arboreal coverage. The presence of this species in traps suggests they explore other substrates due to limited habitat and resource availability (vegetation) in the harsh part of the gradient. The success of $C$. conspicuus zonatus could be explained by their nocturnal foraging and high propensity to relocate their nests (sensu Longino 2004, Pérez-Sánchez pers. obs.). Both behaviors have been related to avoidance of extreme temperatures and aggressive encounters with other species in xeric environments (Andersen 1995, Bestelmeyer 2000). Thus, the coexistence of both species in the arid tip of the region could be based on the temporal (day/night) and spatial (vegetation/soil) niche separation, mediated by interspecific competition and extreme arid conditions in the western Araya (Andersen 1995, Bestelmeyer 2000, Reznikova 2003).

All tests revealed "abnormal" behavior of the data in C2 and with similarities to ant assemblages from eastern more mesic environments (high species richness and evenness). We attribute this result to its location within an alluvial fan with dense and relatively wide vegetation $\left(\approx 800 \mathrm{~m}^{2}\right)$, which could favor colonization and establishment of a more complex myrmecofauna (Pérez-Sánchez 2007, Pérez-Sánchez et al 2012). Even though vegetation, soil properties, and topography were not considered in this paper, we propose that the combined action of these factors could explain specific changes in the ant fauna within the aridity gradient (sensu Mackay et al 1986, Bestelmeyer \& Wiens 2001, Pérez-Sánchez 2007, Pérez-Sánchez et al 2012). The existence of two dominant floral communities, cactus scrubs and thorny shrublands, and the association of the latter with valleys and alluvial fans on the western tip of the peninsula support this argument (Cumana 1999, González et al 2004, Pérez-Sánchez pers. obs.).

In summary, our results suggest changes in ant composition every $11 \mathrm{~km}$ of distance with a clear decrease in species and genera richness, as well as the intensification of numerical dominance with the increasing longitudinal gradient (a proxy for the aridity gradient). Although our results cannot be explained entirely by the aridity gradient, we think microhabitat changes imposed by climate and topography exert a significant pressure on the ant fauna of the region. We consider that the evaluation of microhabitat heterogeneity (vegetation, soil, and temperature) and ant assemblage relationships will allow to accurately discern the factors that mold the ant fauna along the aridity gradient in the Araya Peninsula.

Acknowledgments The authors wish to express their sincere thanks to Aldemar Acevedo and Danniecil Gonzalez (El Papi) for their assistance in the data recording, and José Rafael Ferrer for his advices in the development of statistical tests. We also thank Guayacán Ecological Investigations Center (Centro de Investigaciones Ecológicas de Guayacán, CIEG-UDO) for giving us the best work conditions in Araya. Eglys Gonzalez and Inge Ambrecht made valuable comments on the initial manuscript. We appreciate the funding provided to AJ Pérez-Sánchez by IDEA WILD and the Fondo Nacional de Ciencia y Tecnología (FONACIT) under the framework of Misión Ciencia (contract no. 200701564). We want to thank Marcel Roche Library for cover publication costs.

Open Access This article is distributed under the terms of the Creative Commons Attribution License which permits any use, distribution, and reproduction in any medium, provided the original author(s) and the source are credited.

\section{References}

Andersen AN (1995) A classification of Australian ant communities, based on functional groups which parallel plant life-forms in relation to stress and disturbance. J Biogeogr 22:15-29

Andersen AN (1997) Functional groups and patterns of organization in North American ant communities: a comparison with Australia. J Biogeogr 24:433-460

Araújo LM, Fernandes W (2003) Altitudinal patterns in a tropical ant assemblage and variation in species richness between habitats. Lundiana 4:103-109

Bestelmeyer BT (2000) The trade-off between thermal tolerance and behavioural dominance in a subtropical South American ant community. J Anim Ecol 69:998-1009

Bestelmeyer BT, Agosti LE, Brandão CR, Brown WL Jr, Delabie JHC, Silvestre R (2000) Field techniques for the study of grounddwelling ants: an overview, description, and evaluation. In: Agosti D, Majer J, Alonso J, Schultz T (eds) Ants: standard methods for measuring and monitoring biodiversity. Smithsonian Institution Press, Washington DC, pp 122-145, 280p

Bestelmeyer BT, Wiens JA (2001) Local and regional-scale responses of ant diversity to a semiarid biome transition. Ecography 24:381-392

Colwell RK (2009) Estimates: Statistical estimation of species richness and shared species from samples. Version 8.2. http://purl.oclc.org/ estimates. Accessed 12 June 2012

Colwell RK, Mao CX, Chang J (2004) Interpolating, extrapolating, and comparing incidence-based species accumulation curves. Ecology 85:2717-2727

Cornejo P, Prieto A (2001) Inventarios de reptiles en dos zonas semiáridas del Noreste de la península de Araya, Estado Sucre, Venezuela. Acta Cient Venez 52:265-271

Cumana LJ (1999) Caracterización de las formaciones vegetales de la península de Araya, estado Sucre, Venezuela. Saber 11:7-16

Cumana LJ, Cabeza P (2003) Clave para especies silvestres de angiospermas de la península de Araya, estado Sucre, Venezuela. Ernstia 13:61-93

Cumana LJ, Prieto A, Ojeda G (2000) Flórula de la Laguna de Chacopata, península de Araya, estado Sucre, Venezuela. Saber 12:25-33

Davidson DW (1977) Species diversity and community organization in desert seed-eating ants. Ecology 58:712-724 
Davidson DW (1998) Resource discovery versus resource domination in ants: a functional mechanism for breaking the trade-off. Ecol Entomol 23:484-490

Delsinne T, Roisin Y, Herbauts J, Leponce M (2010) Ant diversity along a wide rainfall gradient in the Paraguayan dry Chaco. J Arid Environ 74:1149-1155

Dunn RR, Sanders NJ, Guénard B (2009) Geographic gradients in the diversity, abundance, size, and ecological consequences of ants. In: Lach L, Parr C, Abbo K (eds) Ant ecology. Oxford University Press, London, pp 38-58, 402p

Ewel J, Madriz A (1976) Zonas de vida en Venezuela. FONAIAP, Caracas, $270 \mathrm{p}$

González LA, Prieto A, Molina C, Velásquez J (2004) Los reptiles de la península de Araya, Estado Sucre, Venezuela. Interciencia 29:428-434

Guevara M, Bergeron Y, McNeli R, Leduc A (1992) Seasonal flowering and fruiting patterns in tropical semi-arid vegetation of Northeastern Venezuela. Biotropica 24:64-76

Gunawardene NR, Majer JD (2004) Ants of southern Carnarvon Basin, Western Australia: an investigation into patterns of association. Rec West Aust Mus 22:219-239

Kaspari M, O'Donnell S, Kercher JR (2000) Energy, density, and constraints to species richness: ant assemblages along a productivity gradient. Am Nat 155:280-293

Legendre P, Legendre L (1998) Numerical ecology. Elsevier Science BV, Amsterdam, 853p

Lentino M, Bruni AR (1994) Humedales Costeros de Venezuela: Situación Ambiental. Sociedad Conservacionista Audubon de Venezuela, Caracas, $188 \mathrm{p}$

Leopardi C, Véliz J, Cumana LJ (2009) Orquideoflórula preliminar de la península de Araya y áreas adyacentes, Estado Sucre, Venezuela. Acta Bot Venez 32:159-177

Lindsey PA, Skinner JD (2001) Ant composition and activity patterns as determined by pitfall trapping and other methods in three habitats in the semi-arid Karoo. J Arid Environ 48:551-568

Longino JT (2003) The Crematogaster (Hymenoptera, Formicidae, Myrmicinae) of Costa Rica. Zootaxa 151:1-150

Longino JT (2004) Ants of Costa Rica. http://ants.biology.utah.edu/ longino/AntsofCostaRica.html. Accessed 15 February 2012

Mackay WP, Silva S, Lightfoot DC, Pagani MI, Whitford WG (1986) Effect of increased soil moisture and reduced soil temperature on a desert soil arthropod community. Am Mid Nat 116:45-56

Marsh AC (1986) Ant species richness along a climatic gradient in the Namib Desert. J Arid Environ 11:235-241

Matteucci SD (1986) Las zonas áridas y semiáridas de Venezuela. Zonas Áridas 4:39-48

McCune B, Mefford MJ (1999) PC-ORD. Multivariate Analysis of Ecological Data: MjM Software Design, Gleneden Beach, Oregon

Medel RG (1995) Convergence and historical effects in harvester ant assemblages of Australia, North America, and South America. Biol J Linn Soc 55:29-44

Mittelbach GG, Steiner CF, Scheiner SM, Gross KL, Reynolds HL, Waide RB, Willig MR, Dodson SI, Gough L (2001) What is the observed relationship between species richness and productivity? Ecology 82:2381-2396
Morton SR, Davidson DW (1988) Comparative structure of harvester ant communities in arid Australia and North America. Ecol Monogr 58:19-38

Oden NL, Sokal RR (1986) Directional autocorrelation: an extension of spatial correlograms to two dimensions. Syst Zool 35:608-617

Oksanen J, Blanchet FG, Kindt R, Legendre P, Minchin PR, O'Hara RB, Simpson GL, Solymos P, Henry M, Wagner S, Wagner H (2011) Vegan: Community Ecology Package. $\mathrm{R}$ package version 2.0-2. http://CRAN.R-project.org/package=vegan

Palacio EE, Fernández F (2003) Claves para subfamilias y géneros. In: Fernández $\mathrm{F}$ (ed) Introducción a las hormigas de la región Neotropical. Instituto de Investigaciones de Recursos Biológicos Alexander Van Humboldt, Bogotá, pp 233-260, 424p

Petrů M, Tielbörger K, Belkin R, Sternberg M, Jeltsch F (2006) Life history variation in an annual plant under two opposing environmental constraints along an aridity gradient. Ecography 29:66-74

Pérez-Sánchez AJ (2007) Composición y Estructura del Ensamblaje de Hormigas en el Enclave Semiárido de Lagunillas, Mérida, Venezuela. Tesis. Universidad de Los Andes, Venezuela, 94p

Pérez-Sánchez AJ, Lattke JE, Viloria AL (2012) Composición y estructura de la fauna de hormigas en tres formaciones de vegetación semiárida de la península de Paraguaná, Venezuela. Interciencia 37 (7): $506-514$

Pfeiffer M, Chimedregzen L, Ulykpan K (2003) Community organization and species richness of ants (Hymenoptera/Formicidae) in Mongolia along an ecological gradient from steppe to Gobi desert. J Biogeogr 30:1921-1935

R Development Core Team (2011) R: A language and environment for statistical computing. R Foundation for Statistical Computing, Vienna, Austria. URL http://www.R-project.org/

Reznikova ZI (2003) Distribution patterns of ants in different natural zones and landscapes in Kazakhstan and West Siberia along a meridian trend. Eurasian Entomol J 2:235-242

Sanders NJ, Moss J, Wagner D (2003) Patterns of ant species richness along elevational gradients in an arid ecosystem. Glob Ecol Biogeogr 12:93-102

Scholes R, Dowty P, Caylor K, Parsons D, Frost P, Shugart H (2002) Trends in savanna structure and composition along an aridity gradient in the Kalahari. J Veg Sci 13:419-428

Schulze ED, Mooney HA, Sala OE, Jobbagy E, Buchmann N, Bauer G, Canadell J, Jackson RB, Loreti J, Oesterheld M, Ehleringer JR (1996) Rooting depth, water availability, and vegetation cover along an aridity gradient in Patagonia. Oecologia 108:503-511

Stanton ML, Palmer TM, Young TP (2002) Competition-colonization trade-offs in a guild of African acacia-ants. Ecol Monogr 72:347-363

Thielen D (2003) Tendencias en la precipitación y la dinámica temporal y espacial de las leñosas en una sabana Neotropical. PhD. Thesis, Instituto de Ciencias Ambientales y Ecológicas, Universidad de Los Andes, Mérida, p. 230

Tieleman BI, Williams JB, Bloomer P (2003) Adaptation of metabolism and evaporative water loss along an aridity gradient. Proc $\mathrm{R}$ Soc Lond B Biol Sci 270:207-214

Whitford WG (1978) Structure and seasonal activity of Chihuahua desert ant communities. Insect Soc 25:79-88 